\title{
On Assessment of Teaching Learning Methodology in First Year Medical Students Of Physiology in a Government Medical College
}

\author{
S. Lakshmi ${ }^{1}$, A.P. Narasimha Rao ${ }^{2}$ \\ ${ }^{1}$ Assistant Professor, Department of Physiology, ${ }^{2}$ Assistant Professor, Department of Pharmacology, \\ Kurnool Medical College, Kurnool, Andhra Pradesh
}

\begin{abstract}
Introduction: The quality of Medical education mediated by many factors like; curriculum, administration, infrastructure, faculty expertise in their knowledge, exposure and training in teaching-learning method.

Material and Method: The study was carried on 150 first-year medical students in the Department of Physiology, Kurnool Medical College, Kurnool. A pre-designed \& pre-validated questionnaire regarding open and close-ended questions about student preferences in various teaching-learning method.

Results: The mean age was found to be 20.11 years. In gender distribution, male students (41\%) were a little higher than female students $(59 \%)$. The most likely method of teaching was a small group discussion (62\%), $41 \%$ is that chalk and Board are most helpful for understanding the topic, $62 \%$ of students said quiz programs are the most enjoyable way of learning. The most influencing quality of a teacher was who had the art of teaching $(43 \%)$.

Conclusion: From our study, we found that students persuaded more towards active learning like Small group discussions practical demos rather than passive theoretical lectures. In addition to that, the attitude of a teaching faculty has got enormous influence on medical students was also perceived.
\end{abstract}

Keywords: Teaching Learning Method, Medical Students, Physiology, Questionnaire Based Study.

\section{Introduction}

The quality of Medical education is many factors like curriculum, administration, infrastructure, patient exposure, faculty expertise in the subject and their knowledge, exposure \& training in teaching-learning methodology - preference for which may differ from college to college. The lecture is one of the most accepted

\section{Corresponding Author:}

Dr. S. Lakshmi

Assistant Professor, Department of Physiology, Kurnool Medical College, Kurnool, Andhra Pradesh e-mail: apnarasimharaokmc@gmai.com

Mobile: 9440713718 standard method in medical education for creating interest among students. ${ }^{1}$ Several teaching method are employed at the undergraduate level to appeal to students with different learning styles like traditional didactic lectures, group discussions, role-playing, case studies, demonstrations through videotapes, problem-based learning. One of the essential ways to strengthen medical education at the content delivery level is to assess student perception about teaching-learning methodology. One of the challenges in medical education is planning a lesson, which makes the student gain maximum knowledge in a short time. ${ }^{2}$

It is a must to all the medical students to acquire adequate knowledge of professionalism and altruism. Any medical teacher needs to meet the educational need of the students regarding the knowledge, attitude and skill. At the same time, it is essential to remember 
that the students represent the population which differs in age, place, ethnicity,different levels of preparedness, learning styles and preferences. ${ }^{3}$

To this purpose, we have conducted a Questionnairebased study in first-year medical students to assess the effectiveness of teaching-learning method in physiology.

\section{Material and Method}

After obtaining approval from the Institutional ethical committee, the study was conducted in the Department of Physiology. The survey carried out on 150 first-year medical students of Kurnool Medical College, Kurnool. All the students were in the age group of 18-22 years. None of them was suffering from any significant medical or psychiatric illness. A pre-designed and prevalidated questionnaire regarding open and close-ended questions about student preferences in various teachinglearning method: informed consent was obtained. Confidentiality of the students was assured so that they could answer the question without any bias. The students were briefed about the survey $\&$ asked to respond freely and fearlessly.

The Data was collected at the end of the second semester with the assumption that students would be better prepared to give informed answers having experienced the different types of teaching and learning environments that are presented to first Year students. The students better prepared to give informed answers, having knowledgeable the different types of teaching and learning environments that presented to first-year students. Moreover, it felt that by this time, students would have received feedback (marks and grades) from different modules that had employed these different teaching and assessment styles. The following criteria structured the sample frame. First-year medical students who are available at the time of the study and willing to participate in the study were included as study population.

Findings: The Data was analyzed in terms of the objectives of the study using descriptive and inferential statistics and presented in tabular and graphical.

The first-year medical students out of 150 , the mean age was found to be 20.11 years. In gender distribution, male students $(41 \%)$ were a little higher than female students $(59 \%)$.

Table 1: Teaching method preferred by the first- year medical students

\begin{tabular}{|l|c|}
\hline Method of teaching & Percentage (\%) \\
\hline Lecture & $16 \%$ \\
\hline Small group discussion & $62 \%$ \\
\hline Practicals & $22 \%$ \\
\hline
\end{tabular}

Table 1 shows that the most likely method of teaching was a small group discussion (62\%), followed by Practicals (22\%) \& Lecture $16 \%$.

Table 2: Teaching aid preferred by the first-year medical students

\begin{tabular}{|l|c|}
\hline Teaching aid & Percentage (\%) \\
\hline Chalk and Bord & $41 \%$ \\
\hline OHP & $11 \%$ \\
\hline PPT & $23 \%$ \\
\hline Demonstration & $25 \%$ \\
\hline
\end{tabular}

Table 2 shows regarding the teaching aid, $41 \%$ felt that chalk and Board are most helpful for understanding the topic, followed by Demonstration (25\%), Powerpoint presentations (23\%), overhead projector sheets $(11 \%)$.

Table 3: Teaching-learning methodologies by firstyear medical students

\begin{tabular}{|l|c|}
\hline Teaching-learning method & Percentage (\%) \\
\hline Student seminar & $12 \%$ \\
\hline Quiz & $62 \%$ \\
\hline Tutorials & $26 \%$ \\
\hline
\end{tabular}

Table 3 shows various teaching-learning methodologies in Physiology. $62 \%$ of students said quiz programs are the most enjoyable way of learning, followed by tutorials $(26 \%)$ where student's seminar $(12 \%)$ was the least likely method of learning.

Table 4: Qualities of a teacher which influence by the first-year medical students

\begin{tabular}{|l|c|}
\hline Qualities of a teacher & Percentage (\%) \\
\hline Personality & $7 \%$ \\
\hline Enthusiasm & $18 \%$ \\
\hline Ability to teach & $43 \%$ \\
\hline Knowledge & $32 \%$ \\
\hline
\end{tabular}

Table 4 shows that students were asked to give an opinion about the qualities of a teacher that influence 
them. The most influencing quality of a teacher was who had the art of teaching (43\%) and good knowledge (32\%). Fallowed by enthusiasm (18\%) and rapport and personality $(7 \%)$ had the lowest ranks in the most preferred qualities of a teacher.

\section{Discussion}

This study showed the most probable method of teaching was small group discussion, regarding the teaching aids felt that chalk and Board is most helpful for understanding, About various teaching-learning methodologies in Physiology students said quiz programs are most enjoyable way of learning, The most influencing quality of a teacher was a teacher who had art of teaching. This study supported by Dr.R.S.Khane et al. ${ }^{4}$ concluded that students were more interested in active learning. The students were also strongly preferred a knowledgeable teacher having excellent skills in teaching and Most of the students liked chalk and talk and small group discussion instead of other method. Shilpa S. Gupta ${ }^{5}$ in their study, found that students were more interested in a conventional mode of learning through. MadhavuluBuchineni et al. ${ }^{6}$ also in their study, observed that the Overall the effectiveness of any lecture mainly depends on the orator's attitude and the tool used for the teaching purpose. Costa et al. ${ }^{7}$ also showed student preference for interactive teaching as the mode of learning.

\section{Conclusion}

From our study, we found that students persuaded more towards active learning like Small group discussions and practical demos rather than passive theoretical lectures. In addition to that, the attitude of a teaching faculty has got enormous influence on medical students was also perceived.

Funding: No funding sources

Conflict of Interest: None declared
Ethical Approval: The study was approved by the Institutional Ethics Committee.

\section{References}

1. Bijli Nanda and Shankarappa Manjunatha Indian medical students' perspectives of problembased learning experiences in the undergraduate curriculum: One size does not fit all J Educ Eval Health Prof. 2013;10:11.

2. Usha Patil, Surekha Vaidya, SmitaJore, Meena Parekh, M.S. Patwardhan Study of Student's Feedback on Present Teaching and Learning Patterns. Int J of Recent Trends in Sci And Tech, 2012; Vol-4 (1), 34-35

3. Shubhada Gade, Suresh Chari, S. Dasgupta. Perception of the Medical Students of a Private Medical College on their Future Career Indian J of Applied. Research,2013; Vol:3, (10), 1-4.

4. Dr.R.S. Khane, Dr.A.A.Joshi. A Questionnaire Based Survey from First Year M.B.B.S. Students About Teaching Learning Method of Physiology in Private Medical College. Paripex - Indian Journal of Research. 2014;3(2):223-25.

5. Shilpa S. Gupta, Ashok D. Rathod. A Study on preferences of I M.B.B.S. Students about teaching -Learning Method. Journal of Education Technology in Health Sciences, January-April, 2016;3(1):20-22.

6. Madhavulu Buchineni et al. Assessment Of Teaching Methodology In Second Mbbs Medical Students - A Study, Asian Academic Research Journal of Multidisciplinary, A.A.R.J.M.D. Nov. 2014, Volume 1, Issue 27, 707-711.

7. Costa, M. L., Rensburg, L. V. \& Rushton, N. Does teaching style matter? A randomized trial of group discussion versus lectures in orthopaedic undergraduate teaching, Medical Education. 2007; 41:214-217. 